University of Nebraska - Lincoln

DigitalCommons@University of Nebraska - Lincoln

USDA Forest Service / UNL Faculty Publications U.S. Department of Agriculture: Forest Service -National Agroforestry Center

2011

\title{
Molecular Identification of Armillaria gallica from the Niobrara Valley Preserve in Nebraska
}

\author{
Mee-Sook Kim \\ Kookmin University \\ Ned B. Klopfenstein \\ USDA Forest Service, nklopfenstein@fs.fed.us
}

Follow this and additional works at: https://digitalcommons.unl.edu/usdafsfacpub

Part of the Forest Sciences Commons

Kim, Mee-Sook and Klopfenstein, Ned B., "Molecular Identification of Armillaria gallica from the Niobrara Valley Preserve in Nebraska" (2011). USDA Forest Service / UNL Faculty Publications. 165.

https://digitalcommons.unl.edu/usdafsfacpub/165

This Article is brought to you for free and open access by the U.S. Department of Agriculture: Forest Service -National Agroforestry Center at DigitalCommons@University of Nebraska - Lincoln. It has been accepted for inclusion in USDA Forest Service / UNL Faculty Publications by an authorized administrator of DigitalCommons@University of Nebraska - Lincoln. 


\title{
Short Communication
}

\section{Molecular Identification of Armillaria gallica from the Niobrara Valley Preserve in Nebraska}

\author{
MeE-SooK KIM ${ }^{1}$ and Ned B. Klopfenstein ${ }^{2}$ \\ Authors' addresses: ${ }^{1}$ Department of Forestry, Environment and Systems, Kookmin University, Seoul 136-702, Korea; \\ ${ }^{2}$ USDA Forest Service, Rocky Mountain Research Station, Moscow, Idaho 83843, USA (correspondence to N. B. \\ Klopfenstein. E-mail: nklopfenstein@fs.fed.us) \\ Received March 6, 2010; accepted May 21, 2010
}

Keywords: Armillaria, genome size, species identification

\begin{abstract}
Armillaria isolates were collected from a unique forest ecosystem in the Niobrara Valley Preserve in Nebraska, USA, which comprises a glacial and early postglacial refugium in the central plains of North America. The isolates were collected from diverse forest trees representing a unique mixture of forest types. Combined methods of rDNA sequencing and flow cytometric measurements of nuclear DNA content determined that all Armillaria isolates collected from the site were A. gallica.
\end{abstract}

\section{Introduction}

Armillaria species are diverse in pathogenicity, host specificity, and environmental requirements. Some Armillaria spp. are aggressive pathogens, while other Armillaria spp. are predominately saprophytic, and may help sustain forest productivity via nutrient cycling. Thus, Armillaria species identification is a critical component for monitoring forest health and understanding forest ecosystem functions. Current classification of Armillaria spp. is based in part on morphology and in vitro compatibility of isolates. In recent decades, molecular genetic methods were developed to augment identification of Armillaria species (Kim et al. 2006), and the nuclear DNA content of North American Armillaria spp. has been determined using laser flow cytometry (Kim et al. 2000).

The Niobrara Valley Preserve is a glacial and early postglacial refugium in the central plains of North America where six major ecosystems converge. The middle Niobrara Valley contains a unique mixture of three forest types (northern boreal, western coniferous, and eastern deciduous) (Kaul et al. 1988). This forest refugium offers a unique opportunity to study biological diversity of this ecosystem that has harboured enriched flora and fauna since early postglacial to glacial times (ca. 9000-12 000 years B.P.). However, little is known about the fungal community associated with tree species in this ecologically unique area, and Armillaria species have not been previously reported from this ecosystem. Because Armillaria fungi can be major drivers of forest ecosystem processes, our objectives were to (i) determine if Armillaria spp. are present on diverse tree species within the Niobrara Valley Preserve forest refugium and (ii) identify any Armillaria spp. that were collected in this forest refugium.

\section{Materials and Methods}

On the Niobrara Valley Preserve in Nebraska, USA (Latitude $42^{\circ} 55^{\prime} 16^{\prime \prime} \mathrm{N}$, Longitude $100^{\circ} 26^{\prime} 21^{\prime \prime} \mathrm{W}$, elevation $791 \mathrm{~m}), 10$ trees were randomly selected within the three forest types present (Table 1). On each tree, major lateral roots were excavated and inspected for external rhizomorphs or internal mycelial fans of Armillaria spp. Samples of Armillaria spp. were collected along with host tree data, which included species and general health status. Armillaria spp. collections were established in culture following the protocol of Hanna et al. (2007).

The protocol of Kim et al. (2006) was used for PCR amplification of the intergenic spacer 1 (IGS-1) region of rDNA. The PCR products of IGS-1 region were sequenced with an ABI 3700 DNA sequencer at the Davis Sequencing Facility (Davis, CA, USA), and the IGS-1 sequences of the Armillaria isolates have been deposited in GenBank (Table 1).

Methods of Kim et al. (2000) were used to determine nuclear DNA content. Nuclei were isolated from mycelia and stained with propidium iodide (PI). Fluorescence of the PI-stained nuclei was analysed at the University of Nebraska-Flow Cytometry Core Research Facilities using a FACScan Flow Cytometer 
Table 1

Species identification of Armillaria isolates collected from the Niobrara Valley Preserve in Nebraska, USA

\begin{tabular}{|c|c|c|c|c|}
\hline $\begin{array}{l}\text { Isolate }^{\mathrm{a}} \\
\text { no. }\end{array}$ & Substrate & $\begin{array}{l}\text { Species identification by DNA } \\
\text { sequence data of IGS-1 }{ }^{\mathrm{b}}\end{array}$ & $\begin{array}{l}\text { Genome size }{ }^{\mathrm{c}} \\
\text { (pg per nucleus) }\end{array}$ & $\begin{array}{c}\text { GenBank } \\
\text { accession no. }\end{array}$ \\
\hline NE01 & Ulmus americana & A. gallica, $A$. calvescens, or $A$. sinapina & $0.184 \pm 0.001$ & GU734129 \\
\hline NE02 & Betula papyrifera & A. gallica, $A$. calvescens, or $A$. sinapina & $0.180 \pm 0.001$ & GU734130 \\
\hline NE03 & Betula papyrifera & A. gallica, $A$. calvescens, or $A$. sinapina & $0.180 \pm 0.001$ & GU734131 \\
\hline NE04 & Betula papyrifera & A. gallica, $A$. calvescens, or $A$. sinapina & $0.177 \pm 0.002$ & GU734130 \\
\hline NE05 & Tilia americana & A. gallica, $A$. calvescens, or $A$. sinapina & $0.169 \pm 0.002$ & GU734131 \\
\hline NE06 & Quercus macrocarpa & A. gallica, $A$. calvescens, or $A$. sinapina & $0.177 \pm 0.002$ & GU734130 \\
\hline NE07 & Pinus ponderosa & A. gallica, $A$. calvescens, or $A$. sinapina & $0.175 \pm 0.001$ & GU734132 \\
\hline NE08 & Betula papyrifera & A. gallica, $A$. calvescens, or $A$. sinapina & $0.170 \pm 0.001$ & GU734130 \\
\hline NE09 & Fraxinus pennsylvanica & A. gallica, $A$. calvescens, or $A$. sinapina & $0.179 \pm 0.001$ & GU734133 \\
\hline NE10 & Populus deltoides & A. gallica, A. calvescens, or $A$. sinapina & $\begin{array}{c}0.179 \pm 0.001 \\
0.177 \pm 0.001^{\mathrm{d}}\end{array}$ & GU734133 \\
\hline
\end{tabular}

${ }^{a}$ Ten isolates (NE01 - NE10) of unknown Armillaria were collected from the Niobrara Valley Preserve.

${ }^{b}$ IGS-1, Intergenic spacer-1 of rDNA. Armillaria isolates were compared with known Armillaria spp. using the GenBank BLAST.

${ }^{\mathrm{c}}$ The standard used for comparison was chicken red blood cell $(2.33 \mathrm{pg} / \mathrm{C})$. The formula used for converting fluorescence intensity values to DNA content is provided by Kim et al. (2000). Each number represents the mean \pm standard deviation of the mean of four replications. Each replication of Armillaria isolate DNA content was based on 10000 scanned nuclei.

${ }^{\mathrm{d}}$ Mean nuclear DNA content of 10 isolates of $A$. gallica.

(Becton Dickinson, San Jose, CA, USA). Each measurement of Armillaria DNA content was based on 10000 scanned nuclei. All flow cytometric analyses were conducted four times per isolate.

\section{Results and Discussion}

Rhizomorphs of Armillaria spp. were found on each of the 10 trees inspected. No signs of pathogenicity (e.g., mycelial fans) were found, and all trees appeared healthy with no symptoms of disease. A total of 10 isolates of Armillaria were collected, representing each of the diverse host trees inspected, and included seven different host species (Table 1).

Based on a GenBank BLAST search, IGS-1 sequences of all Armillaria isolates had maximum sequence identity (99\%) with A. gallica (AY509173.1 for NE01-NE06 and NE08-NE10; AY509172.1 for NE07), A sinapina (AY509168.1 for NE01-NE10), and A. calvescens (AY509165.1 and AY509166.1 for NE01NE06 and NE08-NE10; AY509163.1 and AY509164.1 for NE07) (Table 1). As noted in a previous study, rDNA sequence data alone are not always sufficient for definitive identifications among these closely related Armillaria species (Kim et al. 2006); however, no other DNA sequence-based methods are presently available to identify all North American Armillaria spp.

Nuclear DNA contents of the 10 Armillaria isolates (0.17-0.18 pg per nucleus) are shown Table 1. A histogram of fluorescent events versus amount of fluorescence intensity revealed well-defined peaks of Armillaria isolate nuclei (Fig. 1). A previous study reported that $A$. gallica possesses the largest nuclear DNA content ( $0.17 \mathrm{pg}$ per nucleus) among nine North American Armillaria spp. (0.11-0.17 pg per nucleus), which can be considered a diagnostic characteristic of the species (Kim et al. 2000). Thus, all isolates from this study can be identified as A. gallica, because their nuclear DNA content is very similar to that previously reported for $A$. gallica.

The identification of Armillaria spp. is an essential step in monitoring and predicting Armillaria root disease in forest ecosystems. In this survey, combined methods of DNA sequencing of IGS-1, which showed a strong relationship to A. gallica and closely related species, and measurements of nuclear DNA content
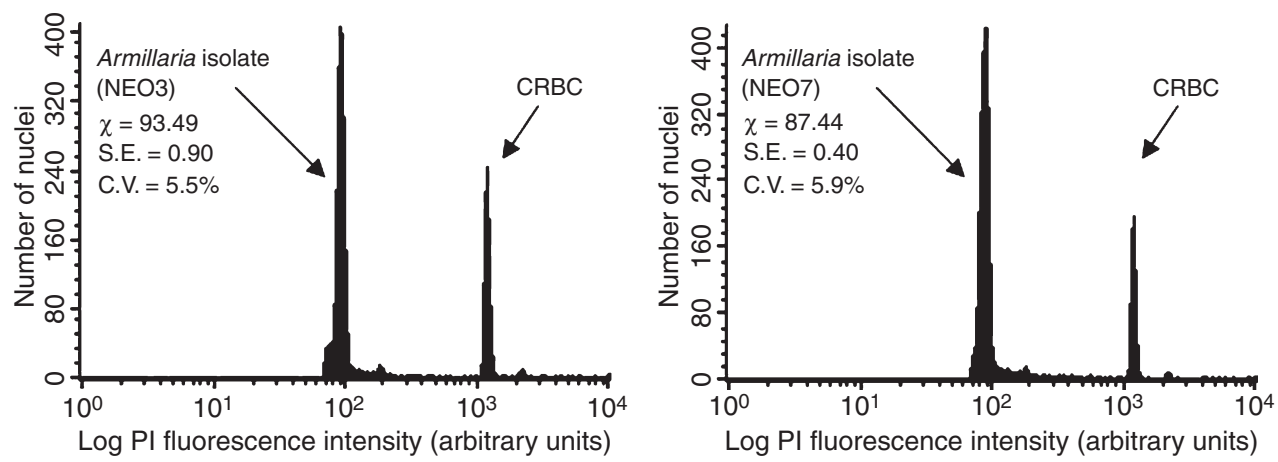

Fig. 1 Representative histograms showing numbers of given fluorescence intensities obtained by flow cytometry for propidium iodide (PI)stained nuclei of Armillaria isolates (NE03 and NE07) and chicken red blood cell (CRBC; 2.33 pg/nucleus). Isolates of Armillaria are described in Table 1. The mean of fluorescence intensities $(\chi)$, standard deviation (SE), and coefficient of variation are (C.V.) listed for the peak 
determined that all Armillaria isolates from this study are A. gallica. To our knowledge, this is the first confirmed report of A. gallica (or any other Armillaria spp.) in the state of Nebraska, USA. Armillaria gallica has been widely categorized as a beneficial saprophyte, an opportunistic pathogen, or an aggressive pathogen (Brazee and Wick 2009). Smith et al. (1992) reported that a single genet of A. gallica $(=A$. bulbosa $)$ remained genetically stable for more than 1500 years. Because the Niobrara Valley Preserve is a protected area with no known tree planting, it seems reasonable to speculate that $A$. gallica may have co-existed in the forest ecosystem of this forest refugium for several millennia. All of the A. gallica isolates in our study were collected from trees that appeared healthy, indicating that A. gallica was not behaving as a pathogen at the time of the survey. However, it should be noted that A. gallica has recently been observed as an aggressive pathogen in some areas of the eastern USA (Brazee and Wick 2009), and it has the potential to contribute to forest decline, especially under increasing stressors such as climate change. Armillaria root disease is typically more severe in highly susceptible tree species and in trees that are maladapted to climate-induced stress (Kliejunas et al. 2009). Thus, it appears likely that climate change will further exacerbate damage from Armillaria root disease; however, accurate identification of Armillaria spp. is needed to monitor and predict climate-change impacts of Armillaria root disease (Klopfenstein et al. 2009). More intensive studies and surveys are needed to understand factors associated with the distribution and ecological behaviour of A. gallica in these forest ecosystems.

\section{Acknowledgements}

We thank the Nature Conservancy, which owns the unique reserve that was surveyed, for encouraging ecological studies on their land.
The project was supported by Research Program 2010 of Kookmin University in Korea, USDA Forest Service-RMRS, and Research Joint Venture Agreement (07-JV-11221662-078). Previous support was provided by Department of Plant Pathology at the University of Nebraska-Lincoln. The authors thank Dr. Anne K. Vidaver for sample collection and guidance, and John W. Hanna for technical assistance.

\section{References}

Brazee NJ, Wick RL. (2009) Armillaria species distribution on symptomatic hosts in northern hardwood and mixed oak forests in western Massachusetts. For Ecol Manage 258:1605-1612.

Hanna JW, Klopfenstein NB, Kim M-S, McDonald GI, Moore JA. (2007) Phylogeographic patterns of Armillaria ostoyae in the western United States. For Pathol 37:192-216.

Kaul RB, Kantak GE, Churchill SP. (1988) The Niobrara River Valley, a postglacial migration corridor and refugium of forest plants and animals in the grasslands of central North America. Bot Rev 54:44-81.

Kim M-S, Klopfenstein NB, McDonald GI, Arumuganathan K, Vidaver AK. (2000) Characterization of North American Armillaria species by nuclear DNA content and RFLP analysis. Mycologia 92:874-883.

Kim M-S, Klopfenstein NB, Hanna JW, McDonald GI. (2006) Characterization of North American Armillaria species: genetic relationships determined by ribosomal DNA sequences and AFLP markers. For Pathol 36:145-164.

Kliejunas JT, Geils BW, Glaeser JM, Goheen EM, Hennon P, Kim M-S, Kope H, Stone J, Sturrock R, Frankel S. (2009) Review of Literature on Climate Change and Forest Diseases of Western North America. Albany, CA, US Department of Agriculture Forest Service, Gen Tech Rep PSW-GTR-225, 54 pp.

Klopfenstein NB, Kim M-S, Hanna JW, Richardson BA, Lundquist JE. (2009) Approaches to Predicting Potential Impacts of Climate Change on Forest Disease: An Example with Armillaria Root Disease. Fort Collins, CO, US Department of Agriculture Forest Service, Res Pap RMRS-RP-76, 10 pp.

Smith ML, Bruhn JN, Anderson JB. (1992) The fungus Armillaria bulbosa is among the largest and oldest living organism. Nature 356:428-431. 